Fiscaoeconomia

E-ISSN: 2564-7504

2021, Volume 5, Issue 2, 793-800

https://dergipark.org.tr/tr/pub/fsecon
Speech Note/Konuşma Notu

Submitted/Geliş: 02.02.2021

Accepted/Kabul: 07.02.2021

Doi: $10.25295 /$ fsecon.936592

\title{
Salgının Ekonomik Yaşama Etkileri ${ }^{1}$
}

\section{The Effects of the Pandemic on Economic Life}

\section{Erinç YELDAN ${ }^{2}$}

Gerek ülkemizde gerekse küresel ekonomide iktisatçılar, profesyoneller, iktisat yönetimleri, ekonomi yönetimleri birçok kararlarla karşı karşıya kaldılar ve ne gibi sonuçlar alındı bunları sizlere kısaca paylaşmak istiyorum. Şimdi bende sunum dosyamı açarak bu konuya başlayayım müsaade ederseniz.

Her şeyden önce Birleşmiş Milletler Kalkınma ve Ticaret Konferansı Örgütü (UNCTAD) geçtiğimiz haftalarda yayınladığı raporda 2020 yılında küresel ekonomide $\% 4,3^{\prime} \mid u ̈ k$ bir daralma yaşanacağını vurguladı. Küresel imalat sanayinde daralma \%11'e ulaşacak. Bunlar iktisadi kayıpların ön tahminleri.

Uluslararası Çalışma Örgütü (ILO) yepyeni bir metodoloji uygulamaya başladı. Saatlik çalışma süreleri üzerinden gidiyor ve küresel çapta dünya ekonomisinde, dünya işgücü piyasalarında çalışılan saatlik süre kaybının \%11'e ulaşacağını tahmin etmektedir. Bunu eğer tam zamanlı eşdeğer iş kaybına çevirirsek 400 milyon kişilik bir işsizlik, bir iş kaybı anlamına geliyor. Bir karşılaştırma için COVID Krizi öncesi dünyada toplam açık işsiz sayısı 200 milyondu. Yani bu durum iki misli daha fazla iş kaybı yaşanan dünya işgücü piyasalarıyla bizi karşı karşıya bıraktı. Bu rakamı bir kere daha vurgulayacağım. DíSK araştırma dairesindeki uzman arkadaşlarımız aynı metodoloji ile bu hesabı Türkiye için yaptığı zaman Eylül ayındaki en son daha dün yayınladığı raporda 1 milyon 706 bin tam zamanlı eşdeğer iş kaybının yaşandığını ülkemizde vurguladı.

Neler yapıldı? UNCTAD ve IMF tarafından paylaşılan verilere göre ülkelerin yıl boyunca uyguladığı iktisadi canlanma paketlerinin toplam tutarı 12 trilyon dolar düzeyinde. Ama bu bir ortalama rakam. Dünya milli gelirler toplamı kabaca 70 trilyon dolar düzeyinde. Kabaca dolayısıyla \%8'lik bir hasıla oranı kadar bir canlandırma paketi uygulanmıs. Ama her zaman olduğu gibi kapitalizmin gerçekleri burada da karşımıza çıktı. Gelişmiş ülkelerde uygulanan doğrudan mali harcama ya da gelirden yani vergi gelirlerinden veya başka gelirlerden vazgeçme yani doğrudan fiskal mali politikanın uygulandıkları genişleyici maliye politikaların milli gelire oranı $\% 9,5$ oranına kadar ulaşıyor gelişmiş ülkelerde bu. Bu rakama bir de parasal genişleme, öz kaynak desteği, kredi garantisi, teşviklendirilmiş kredi gibi parasal destekler gibi mili gelirin \%11,8'ine varan destekleri eklediğimiz vakit gelişmiş ülkelerde milli gelirin \% 20'sini

\footnotetext{
${ }^{1}$ Bu çalışma, Prof. Dr. Erinç Yeldan'ın, 12 Aralık 2020'de 21. Yüzyıl İçin Planlama Grubu tarafından düzenlenen "Salgın ve Sağlık 2, Salgının Toplumsal ve Ekonomik Yaşama Etkileri" başlıklı konferanstaki konuşma metnidir.

2 Prof. Dr., Kadir Has Üniversitesi, erinc.yeldan@khas.edu.tr, ORCID: 0000-0002-3123-4374
} 
Yeldan, E. (2021). Salgının ekonomik yaşama etkileri.

Fiscaoeconomia, 5(2), 793-800. doi: 10.25295/fsecon.936592

aşan oranlarda bir destekleme paketi uygulandığını görüyoruz. Öbür tarafta gelişmekte olan ülkelerde bu ekonomik tedbirler sadece \%3,8'lik bir mali destek, \%2,4'lük de bir parasal destek olarak hesaplanıyor. Kişi başına gelişmiş ülkelerde 3500 dolarlık bir destek, gelişmekte olan ülkelerde de sadece 160 dolar düzeyinde bir destekten bahsetmiş oluyoruz.

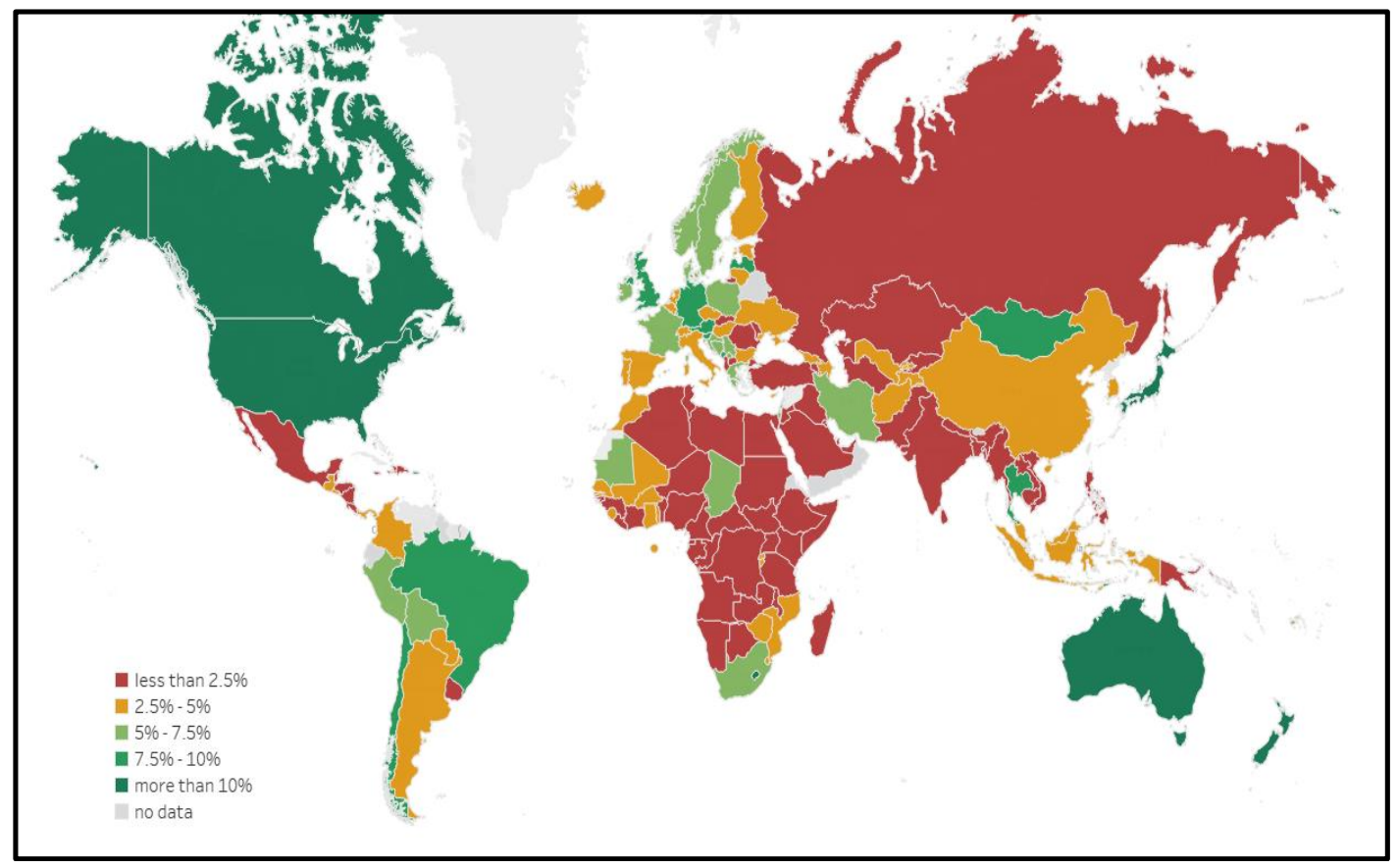

IMF'nin bir haritası var. Bu haritaya göre milli gelire oranla \%.2,5 ve daha az oranda yapılan mali paket yani doğrudan mali destekler kırmızıyla gösterilmiştir. Türkiye'de bu grupta. Türkiye'nin de uluslararası standartlarda doğrudan bir mali canlandırma paketi uygulamakta son derece düşük bir adım attığını görülmektedir. Yine biraz evvelki rakamların yansımasıdır bu. \%10'un üzerinde destek açıklayan ülkeler ABD, Kanada, Avustralya'dır. Avrupa ülkelerinin çoğunda \%7,5 ile \%10 arası, \%5 ile \%10 arası boyutlarda ama gelişmekte olan ve az gelişmiş ülkeler, çoğu Afrika ülkeleri, Hindistan ve Uzak Asya ülkeleri, Çin \%5'in altında. Dolayısıyla mavi paketlerin boyutu ciddi anlamda gelişmekte olan ülkelerin aleyhinde bir tasarruf.

Türkiye neler yaptı?

IMF'nin yayınladığı resmi veriler Eylül başına kadar gayri safi yurt içi hasılamızın kabaca \%13'üne \%12,8'ine ulaşan toplam bir mali destek paketi uygulandığını gösteriyor. 573 milyar Türk lirası. Bunun 123 milyarı bütçe içinden karşılanmış geri kalan kabaca 450 milyar Türk lirası bütçe dışı kaynaklardan gelmiş. Nedir bunlar? Kabaca özetliyorum kredi garantisi. Gayri safi yurt içi hasılanın 6,8'i yarısı hemen hemen. Kamu bankaları tarafından uygulanan kredi erteleme. Milli gelirin \%1,5. Kamu bankalarına sermaye aktarımı milli gelirin \%0,5'i.

Şimdi bakarsanız \%12,8'i neredeyse zaten \%10'luk bölümü kredi ve vatandaşı, şirketleri, Türkiye insanını borçlandırma, borçlarını erteleme, daha rahat koşullarda kredi kullanmak üzerinden ama özü itibariyle borç edinimi üzerinden kurgulanan birer destek programı. Gerçekten reel ekonomiyi doğrudan etkileyecek, canlandıracak bir tasarruf örneğin kısa çalışma ödeneği başlığı altında ve bu da çoğunlukla gene çalışanlara değil çalıştıranlara işveren 
Yeldan, E. (2021). Salgının ekonomik yaşama etkileri.

Fiscaoeconomia, 5(2), 793-800. doi: 10.25295/fsecon.936592

kesime bir rahatlama anlamına gelen ve gayri safi yurt içi hasılamızın binde 4'üne yarım puanla bile ulaşmayan bir destekten ibaret oldu.

Türkiye'nin bu tercihi yine IMF verilerinden elde ettiğim yükselen piyasa yükselen piyasayı burada tırnak içine alıyorum. Bu kavram son derece tartışmalı, kötü anlatımlara açık. Gelişmekte olan ülkeler kavramını ben tercih ediyorum ama başlık yükselen piyasa ekonomisi olduğu için ve orta gelirli ülkeleri kapsadığı için ben de başlığa sadık kalmak uğruna bunu tırnak içinde sizlerle paylaşıyorum.

Pembe kutucuklar özkaynak, borçlandırma, kredi kartı garantileri gibi milli gelirin biraz evvel bahsettiğim gibi neredeyse \%13'üne ulaşan bir büyüklük Türkiye'de. Diğer ülkelerde bunun yanında kırmızı kutucuklar gerçekten mali politika mali harcamalar ve vazgeçilen gelirler üzerinden kurgulanıyor. Türkiye'nin buradaki tercihinin aslında reel ekonomiyi canlandırmaya yönelik mali harcama veya vergilendirmeden vazgeçme gibi doğrudan bir mali harcama paketinden değil de doğrudan doğruya finans sermayesinin çalışmasını canlandıran kredi, ucuz teşvik, ucuz öz kaynak ve kredi desteği gibi tamamı ile parasal ve borçlanmayı özendiren bir teşvik sisteminin Eylül ayına kadar 2020 yılında uygulanmış olduğunu görüyoruz.

\section{EMERGING MARKET AND MIDDLE-INCOME COUNTRIES}

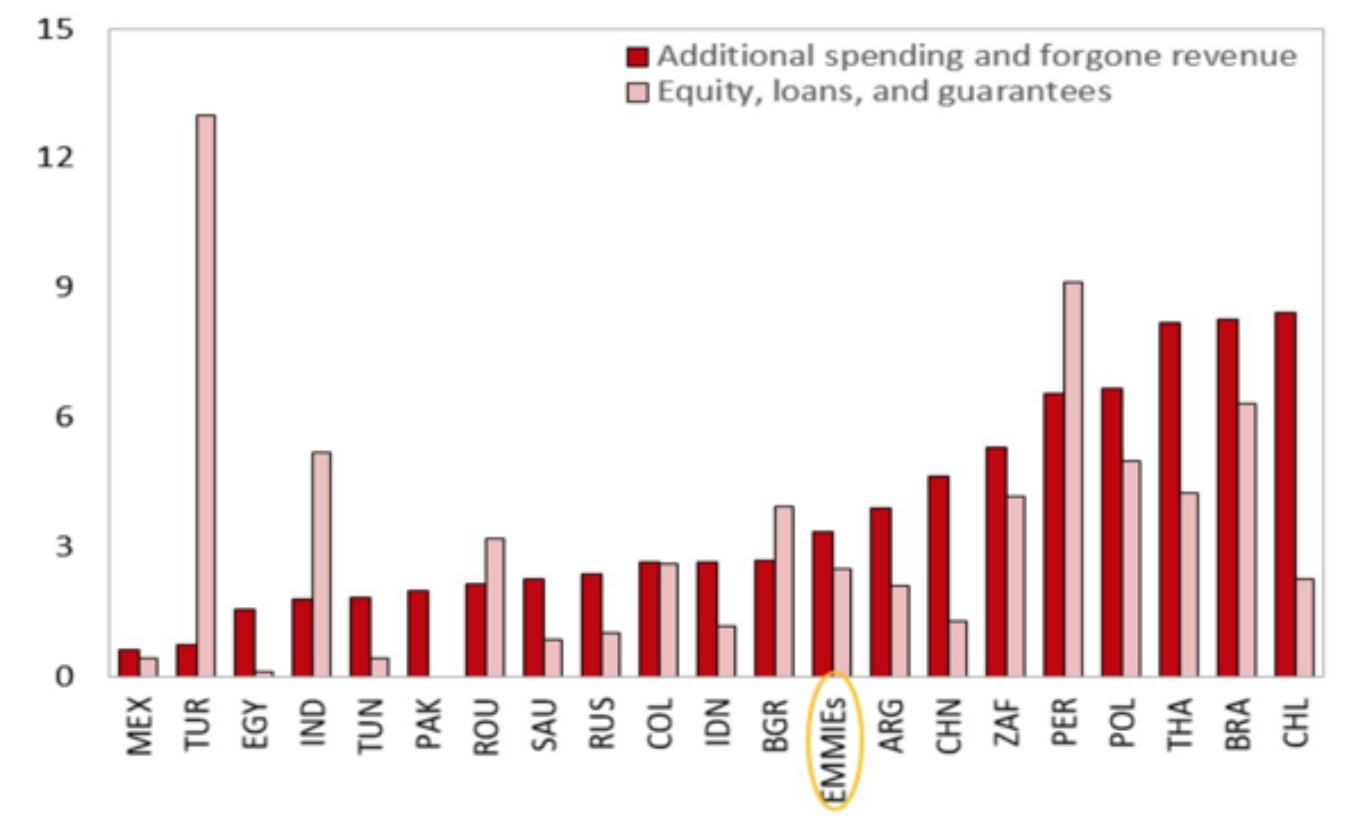

Nedir bu tercihin sonuçları? Iktisaden ne gibi sonuçlar elde ettik? G20 zirvesi için IMF çalışanlarının Kasım ayında yazdıkları bir rapordan yararlanacağım. Türkiye ve Türkiye'ye benzer komşularımız, gelişmiş, gelişmekte olan, orta gelirli ülkelerin karşılaştırmaları yapılacaktır. Grafikteki yatay eksende potansiyel milli gelir üretim büyümesinden sapma yani potansiyel milli gelir kayıplarımız yer almaktadır. Türkiye'de \%4,6, Hindistan'da \%10, Meksika'da \%6, Rusya'da \%2, Japonya'da \%3, Avrupa Birliği üye ülkelerinde \%5, Amerika'da \%3,8 olarak hesaplanmaktadır. Bunlar üretim kayıplarını veriyor. Grafiğin dikey eksinde üretimin yanında bir de enflasyon hedefinden sapmalar yer almaktadır. Türkiye'de 2020 yılında hedeflenen enflasyondan ortalama 7 daha fazla enflasyon yaşanmıştır. Bu enflasyon 
Yeldan, E. (2021). Salgının ekonomik yaşama etkileri.

Fiscaoeconomia, 5(2), 793-800. doi: 10.25295/fsecon.936592

oranı değil dikkatinizi çekerim. \%8'le başlayarak sonra \%12'ye kadar çıkan ve 2020 boyunca ortalama olarak hedeflediğimizden 7 puan daha yüksek bir enflasyon yaşadık. Enflasyon ve milli gelir performansı her ikisi de bir başka iktisadi sorun kuşkusuz. Türkiye ekonomisinin nasıl ayrıştığını özellikle enflasyonda \%20 gibi yüksek bir enflasyon yaşarken potansiyel üretimden sapma konusunda da birçoğu Avrupa Birliği üyesi olmakla, Rusya, Brezilya ve Japonya gibi ekonomileri geride bıraktığını görülmektedir. Gerek potansiyel üretimden sapma gerekse de enflasyon hedefinden sapma bakımından da ortalamanın daha üzerinde kalarak kötü bir performans sergilediğimize G20'ye sunulan IMF raporundan ulaşıyoruz.

\section{EMERGING MARKET AND MIDDLE-INCOME COUNTRIES}

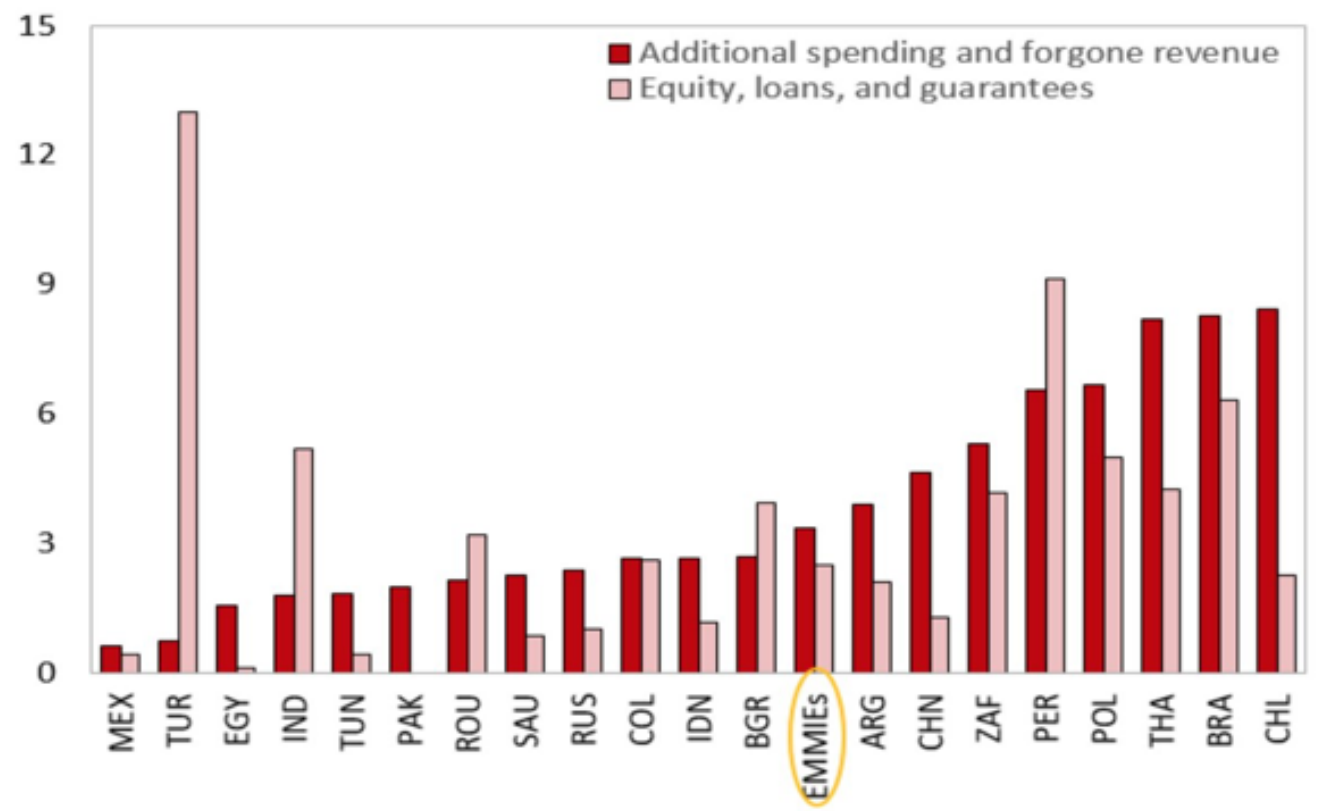

Bir de konunun işsizlik boyutu var. Burada planlanmış mali desteklerin gayri safi yurt içi hasılaya oranı görülmektedir. "Discretionary" terimini ben Türkçeye iradi mali destek olarak çevirdim. Planlanmış mali destek veya arzulanan mali destek diyelim. Mavi kutucuklar bunları gösteriyor. Sol taraftaki ve sağ taraftaki eksenden boyutlarını görüyorsunuz. Türkiye'nin neredeyse mali desteği yok. Arzu edilmiş, planlanmış mali harcamaların milli gelire oranı İspanya'da \%3,5, Brezilya'da \%8, Meksika'da \%4 olarak gerçekleşmektedir. Kırmızı kutucuklar da potansiyel istihdamdan kayıpları veriyor. Potansiyel istihdamdan kayıp, işsizlik oranı değil istihdam kayıpları. İşsizlik oranına şimdi geleceğim. Büyük bir kavram kargaşası var işsizlik meselesinde. Orda da bir iki cümle söyleyeceğim ama bunlar potansiyel istihdam kayıplarımız. Türkiye'nin uyguladığı bu \%12,8 milli gelire ulaşan bu destek paketinin aslında reel ekonomi ile değil finans dünyasının spekülatif kumarhane masası ile ilgili olduğu ve biz bunlarla vakit kaybederken gerek istihdam gerek enflasyon ve dolayısıyla gerek üretim kayıpları bakımından Türkiye ekonomisinin 2020'yi hakikaten bir kayıp fırsatlar yılı olarak geçirmiş olduğunu görüyoruz. Bu ana kadar kullanmış olduğum veriler Uluslararası Çalışma Örgütü, IMF, OECD ve bizim resmi kaynaklarımız oldu. 
Yeldan, E. (2021). Salgının ekonomik yaşama etkileri.

Fiscaoeconomia, 5(2), 793-800. doi: 10.25295/fsecon.936592

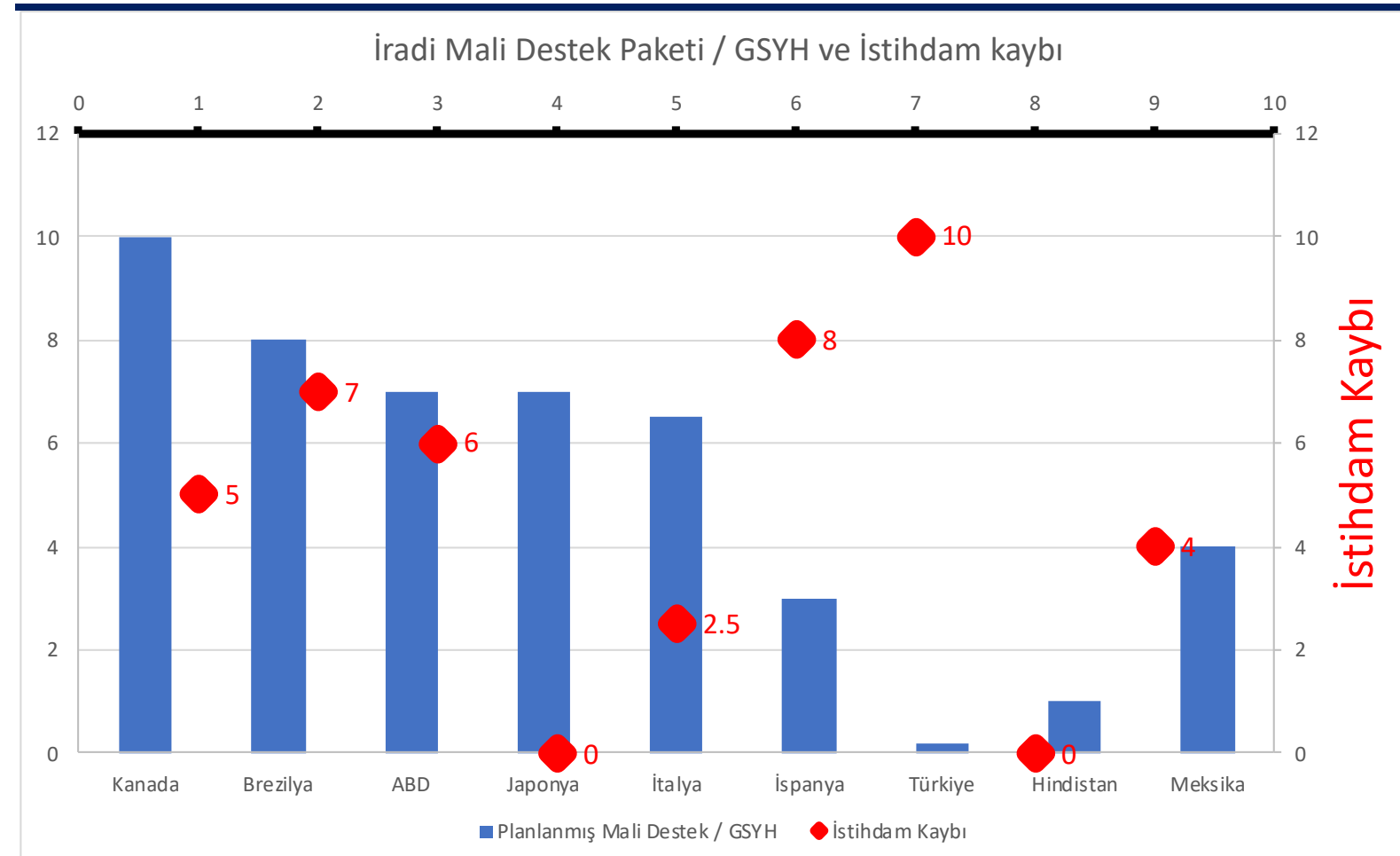

Şimdi biraz daha sadede gelelim. Kısıtlı vaktimin altında. DisK araştırma dairesindeki meslektaşlarımız dediğim gibi bu hafta başında yayınlanan hanehalkı işgücü istatistiklerinden yola çıkarak bir dizi kavramı bizimle paylaşıyorlar. Hatırlatmak için özel olarak sunuyorum. 2019 Eylül'ünden 2020 Eylül'üne 733 bin kişi daha az istihdam ediliyor Türkiye'de. İş arayıp bulamayanlar diye ben yeni bir kavram kullanmak zorundayım. Bu Türkiye'de işsizlik oranı olarak diye geçiyor. Tüik'iN yayınladığı rakam bu. Şimdi işsizlik oranı \%12,7 ve düşüyor diye buştulandı. Fakat nedir bu işsizlik oranı? Bu oran kavram gereği aktif olarak iş arayıp da bulamayanlar. İş arayıp da bulamayanlar 550 bin kişi azalmış durumda geçen seneye göre. İş başında olanlar var bunun yanında gerçekten iş yapan, işin başında olanlardaki azalma da 1 milyon 200 bin kişiye yakın bir rakam. 1 milyon 200 bin kişi iş başında değil. Bir de daha doğrusu iş başında olanlardaki azalış. Bir de iş başında hiç olmayanlar var. Yani iş başına da gitmeyenler var. Bunlar 450 bin kişi artış göstermiş. Konuşmamın başında belirttiğim Uluslararası Çalışma Örgütü'nün saatlik çalışma sürelerindeki kayıp üzerinden eş değer istihdam kaybına çevirdiği oranı da hesaplıyor DiSK uzmanları. Bu da 1 milyon 706 bin kişilik bir artış gösteriyor. Şimdi iş arayıp bulamayanlara, ümidini kaybeden ve iş aramaktan vazgeçen fakat iş olduğu takdirde çalışmaya gönüllü ama açık işsizlik oranı içinde geçmeyen milyonlarca insan var. Bunları da DiSK 9 milyon 470 bin kişi olarak bize Tüik rakamından çıkartıyor. Bu oran işgücüne oran olarak $\% 26$.

Bu geniş tanımlı işsiz sayısının cinsiyet bazındaki kırılımları daha da çarpıcı. Biraz evvel vurguladığım iş arayıp bulamayanlar yani açık işsizlik oranı \%12 Türkiye'de. Bu kadınlarda \%16'ya, erkeklerde \%12'ye ulaşıyor. Bir de umudunu kesen geniş tanımlı biraz evvel \%26 olarak Türkiye genelinde verdiğim rakam kadın emekçilerde \%35'e kadar yükseliyor. Yani iş aramaktan umudunu kesmiş, iş aramıyor ama çalışmaya hazır ve işsiz. Bütün bunlardan kadın emekçilerin her üçünden birisinin işsiz statüsünde olduğu gözüküyor. Türkiye ortalaması \%26, 
Yeldan, E. (2021). Salgının ekonomik yaşama etkileri.

Fiscaoeconomia, 5(2), 793-800. doi: 10.25295/fsecon.936592

\begin{abstract}
kadın emekçilerde \%35, erkeklerde de kabaca \%22. Dolayısıyla istihdamın cinsiyet boyutları
\end{abstract} bambaşka.

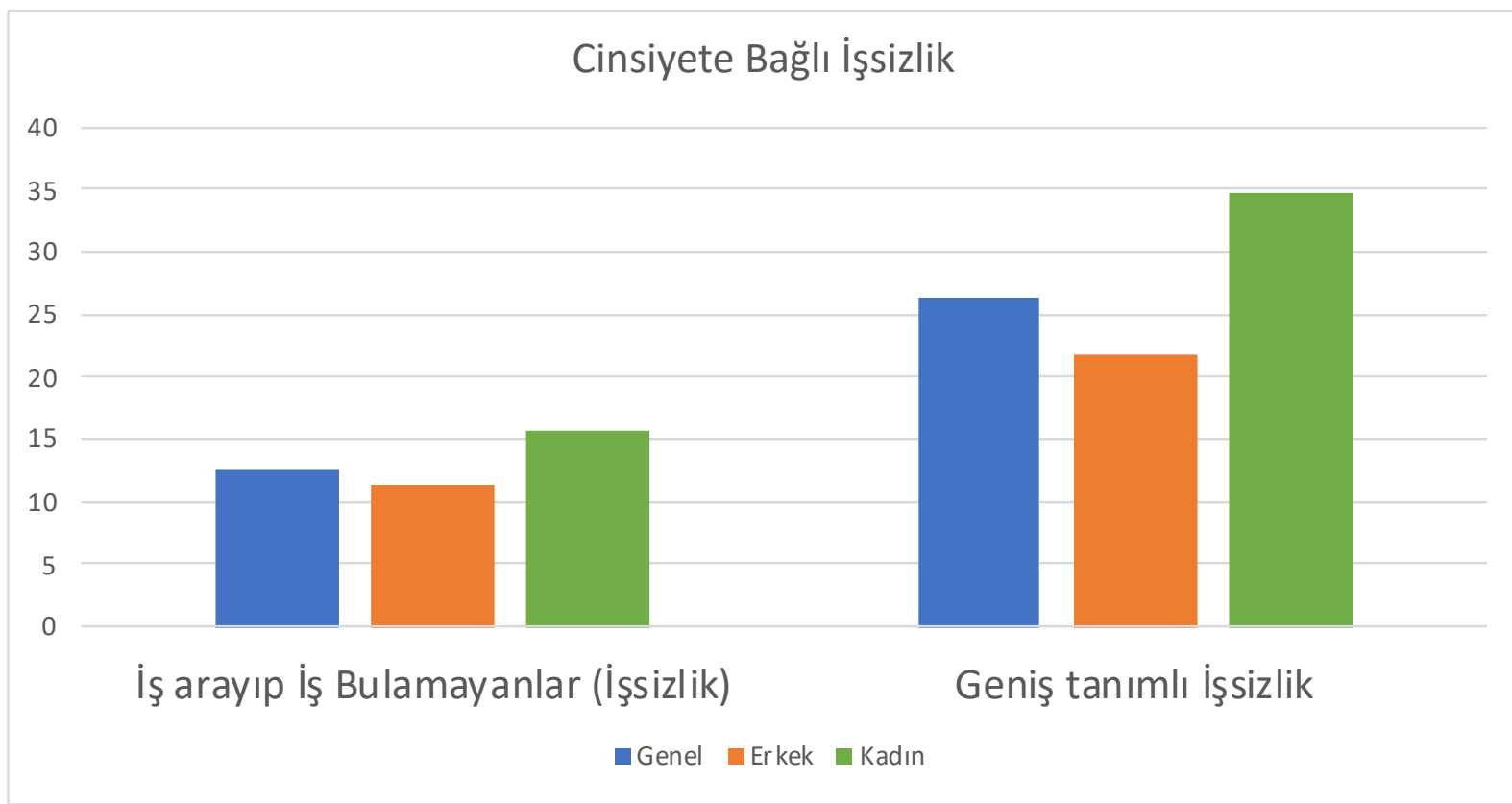

Bütün bunların bedeli ne oldu? Bütün bunlar Türkiye'nin ciddi anlamda bir mali harcama yapmamasına karşın 2019 Eylül'den 2020 Eylül'üne kadar merkezi yönetimin toplam borcunun neredeyse \%20 arttığını, 1,3 Trilyon Türk lirasından 1,9 Trilyon Türk Lirasına kadar toplam borç stokumuzun yükseldiği bir konjoktürle karşı karşıyayız. Türkiye yüksek bütçe açığı veren düşük mali harcama politikası izleyebilen ve ekonomisini ivmelendirememiş, enflasyonda da ciddi anlamda yüksek bir enflasyon ile Türkiye insanının cezalandııldığı bir ekonomi olagelmiş durumda.

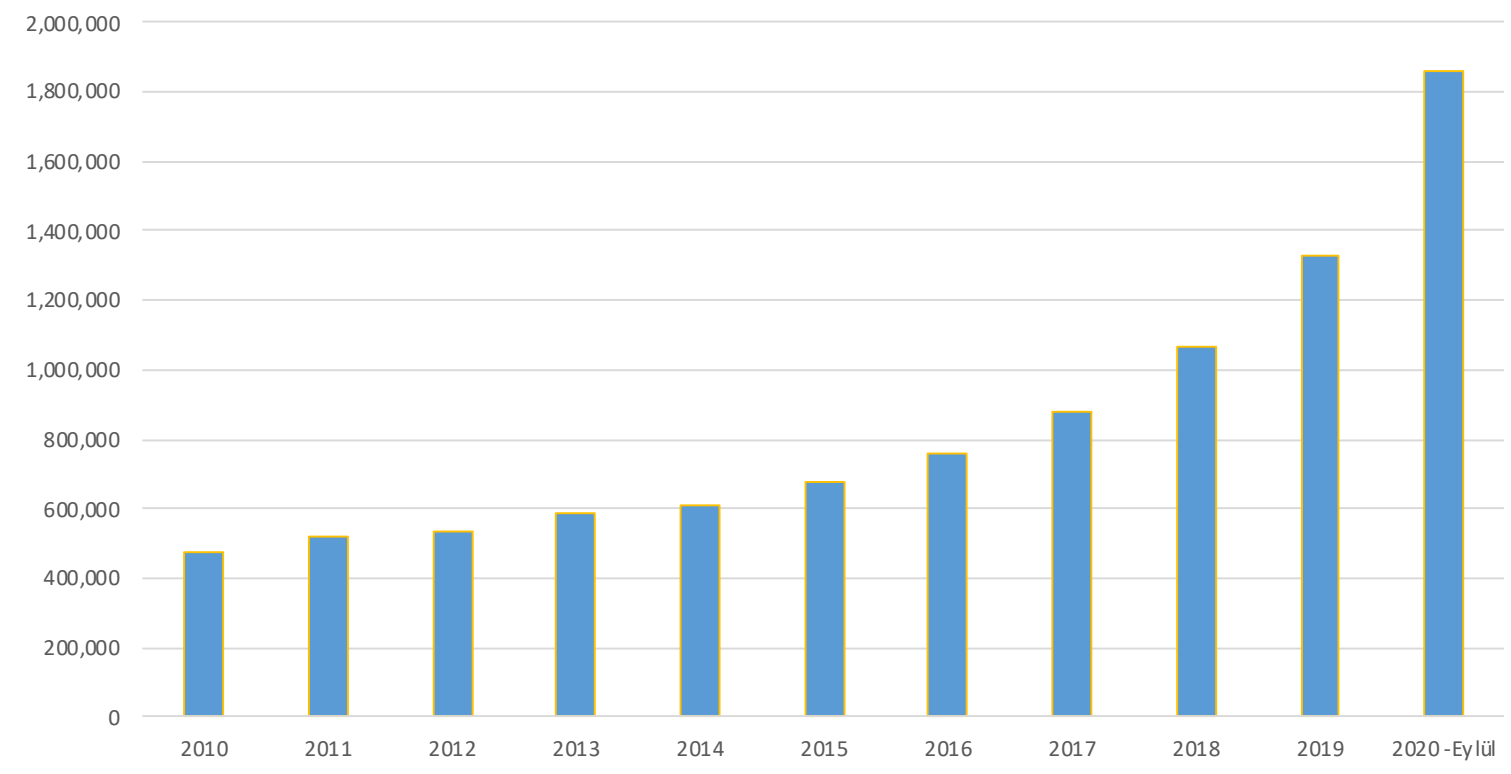




\begin{abstract}
Bütün bunlar yine TÜik'in hanehalkı gelir istatistiklerinden derlediğimiz 2019 yılı en son verileridir. En alttaki \%5'lik milli gelirde alan payların çakılı kaldığını, 2006'dan 2020'ye kadar en üst gelir grubunun da 2014-2015'ten sonra payını neredeyse 3 puan yükselttiği Türkiye'de gelir eşitsizliğinin en üst $\% 20^{\prime}$ lik ile en alt $\% 5$ gelir payları arasında ciddi bir fark olduğunu görmekteyiz.
\end{abstract}

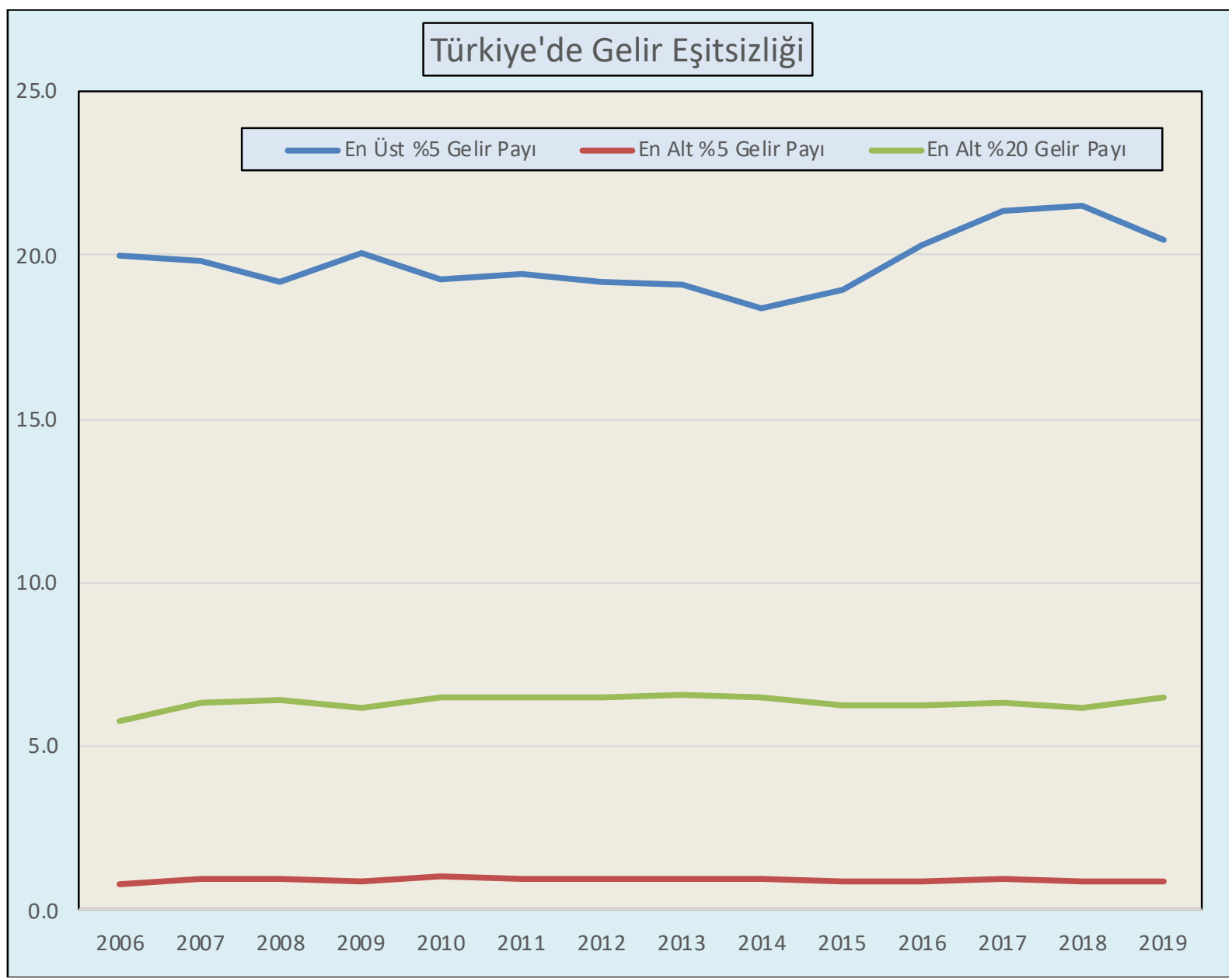

Bundan sonra alternatif olarak ne yapılabilir konusunda sadece bir iki tane ipucu vereceğim. Malum 21.yy'da planlamayı tartışıyoruz. Bir planlama tecrübesi oldu ve sevgili çalışma arkadaşım Orta Doğu Teknik Üniversitesi Ekonomi Bölümünden Profesör Doktor Ebru Voyvoda ile beraber bu Mayıs ayında daha pandeminin ilk günlerinde bilim akademisinin Sarkaç dergisinde, hem internet sitelerinde hem de basılı olarak ve Efil Yayınevi tarafından çıkmış Salgının Ekonomisi adlı kitaptan bir bölüm olarak yayınlandığı çalışma.

Bu çalışmada biz şunu dedik. Doğrudan bir emek gelir desteği yapsak ve bu emek gelir desteğinde kamunun tüketim harcamalarını \%20 artırsak, işsiz kalan kişilere asgari ücretin üzerinde ortalama iş̧̧i ücretinin (asgari ücretin \%20 fazlası) \%50'si kadar bir gelir transferi versek ve bunun yanında küçük ve orta boy şirketlerin ve kendi hesabına çalışanlar kesimine de yine vergi iadeleri veya doğrudan destek olarak bir mali harcama politikası uygulasak bu harcama politikasının bedeli 123 Milyar Türk Lirasıydı. Türkiye unutmayın IMF tanımına göre parasal destekler dahil 570 Milyar Türk lirası bir para harcadı. Bu milli gelirin \%12'siydi. Biz sadece \%3'ü ile böyle bir paketin neticesinde milli gelirde kayıplarda çok önemli telafiler, 


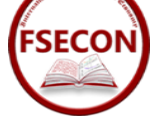

Yeldan, E. (2021). Salgının ekonomik yaşama etkileri.

Fiscaoeconomia, 5(2), 793-800. doi: 10.25295/fsecon.936592

2019'a göre yine hala kayıp fakat COVID pandemisinin rakamlarına göre kabaca \%20'lik bir milli gelir desteği ve bütçe açığında da daha düşük bir bütçe açığı olabileceğini göstermiştik. Vaktim kısıtlı kaldığı için böyle bir çalışmanın bulgularına daha fazla girmeyeceğim fakat ana hatlarıyla size sunduğum kaynaktan hem de bu Türkiye'nin izlemiş olduğu politikaya Mart, Nisan. Mayıs aylarından başlayarak doğrudan gelir desteklerini hedefleyen paket ile Türkiye hem üretimde hem istihdamda hem de bütçe dengelerinde göreceli olarak-yanlış anlaşımasıngöreceli olarak çok daha uygun sonuçlar alabileceğimizi öngörmüştük. 